\title{
Prevalence and progression of macroscopic lesions in Orbicella annularis and $O$. faveolata on shallow fringing reefs of St. Kitts
}

\author{
Elize H. R. Dorrestein ${ }^{1}$, Anne Conan ${ }^{1}$, Ligia L. Pentzke-Lemus ${ }^{1}$, Gregory Hartman ${ }^{1}$, \\ Saundra H. Sample ${ }^{1}$, Michelle M. Dennis ${ }^{1,2, *}$ \\ ${ }^{1}$ Center for Conservation Medicine and Ecosystem Health and Department of Biomedical Sciences, \\ Ross University School of Veterinary Medicine, Basseterre, St. Kitts and Nevis \\ ${ }^{2}$ Present address: Department of Biomedical and Diagnostic Sciences, University of Tennessee College of Veterinary \\ Medicine, Knoxville, Tennessee 37996, USA
}

\begin{abstract}
The endangered corals Orbicella annularis and $O$. faveolata are crucial to Caribbean reefs because of their large size and contribution to reef framework. The objective of this study was to describe the prevalence and progression of macroscopically evident lesions affecting Orbicella spp. in shallow fringing reefs in St. Kitts. Cross-sectional surveys in the spring of 2017 demonstrated 8 predominant lesion patterns affecting $59 \%$ of corals (95\% CI: 55.8-62.1\%), including annular yellow-brown pigmentation, focal brown pigmentation, focal bleaching, diffuse bleaching, annular black surface deposit, focal tissue loss with skeletal erosion, focal grey pigmentation, and growth anomaly. Longitudinal surveys of 47 tagged corals were performed from August 2016-May 2017 to track lesion progression. The 2 most common lesions, annular yellow-brown pigmentation $(n=30)$, and focal brown pigmentation $(n=21)$, showed mean $( \pm S D)$ partial colony mortality growth of $0.26 \pm 0.5$ and $0.21 \pm 0.45 \mathrm{~cm}^{2} \mathrm{~d}^{-1}$, respectively. Annular pigmentation progression severity was associated with a marginating band of bleaching (ordinal odds ratio $[\mathrm{OOR}]=$ $11.0)$, and yellow rather than brown color $(\mathrm{OOR}=3.8)$. Bleaching lesions $(\mathrm{n}=13)$, occurring during a time of elevated sea surface temperature, were most severe during October-December 2016, and persisted through April 2017, months after heat stress had subsided. Annular black surface deposits $(n=3)$ were associated with rapid progression of acute tissue loss, whereas focal tissue loss with skeletal erosion $(n=2)$ regressed within months, and focal grey pigmentation $(n=2)$ was quiescent for the length of the study. This study enforces concern for the extent to which Orbicella spp. are declining due to disease.
\end{abstract}

KEY WORDS: Bleaching - Dark spots disease - Disease - Growth anomaly · Pathology · Scleractinia $\cdot$ Yellow band disease $\cdot$ Orbicella

\section{INTRODUCTION}

In recent decades, coral reefs have substantially declined around the world. Disease is an important contributing factor, especially in the Caribbean (Carpenter et al. 2008), with average coral cover on Caribbean reefs declining from $34.8 \%$ in the 1970 s to $16.3 \%$ in 2012 (Jackson et al. 2014). For millennia, the primary builders of reef framework in the Carib-

\footnotetext{
${ }^{*}$ Corresponding author: mdenni12@utk.edu
}

bean have been Acropora spp. (A. palmata and A. cervicornis) and Orbicella (formerly Montastraea) spp. (O. annularis, O. faveolata, and O. franksi; Aronson \& Precht 2001). In the past $40 \mathrm{yr}$, this has dramatically changed. In the early 1980s, Acropora spp. populations were drastically reduced by the emergence of white band disease (Gladfelter 1982) and were later categorized as Critically Endangered by the International Union for Conservation of Nature

(C) The authors 2020. Open Access under Creative Commons by Attribution Licence. Use, distribution and reproduction are unrestricted. Authors and original publication must be credited. 
(IUCN; Aronson et al. 2008a). Subsequently, over the last $15 \mathrm{yr}$, Orbicella spp. have also rapidly declined (Bruckner 2012, Edmunds 2013), and are presently categorized as Endangered by the IUCN and listed as threatened by the United States Endangered Species Act (Aronson et al. 2008b).

Orbicella spp. are large scleractinian corals, often achieving over $1 \mathrm{~m}$ in diameter, that grow slowly (average growth rate: $<1 \mathrm{~cm} \mathrm{yr}^{-1}$ ) and live for centuries (Gladfelter et al. 1978). These corals are especially abundant in shallow $(<10 \mathrm{~m})$ semi-protected reefs (Aronson et al. 2008b). Previously considered robust and even hurricane resistant (Bythell et al. 2000), their decline has been attributed to disease, fish predation, and increased competition with algae and sponges (Bruckner 2012). Population recovery is unlikely, as sexual reproduction only occurs during annual mass spawning events and larval recruitment is uncommon (Szmant 1991).

St. Kitts and Nevis comprise a 2-island nation in the north-eastern Caribbean, and are a small-island developing state economically dependent on tourism. St. Kitts has $167 \mathrm{~km}$ of coastline with a narrow ocean shelf supporting coral reefs. Living coral cover is $<15 \%$ in most areas surveyed, and Orbicella spp. are among the most abundant corals, accounting for around 18\% of corals (Bruckner \& Williams 2012). The largest $O$. annularis and $O$. faveolata colonies are typically found on shallow fringing reefs in St. Kitts ( $<6 \mathrm{~m}$ depth). There has only been one study addressing coral disease in St. Kitts: a survey done in 2011 evaluated bleaching prevalence across 25 reefs, the majority of which were fringing and patch reefs $>6 \mathrm{~m}$ deep (Bruckner \& Williams 2012). Thus, the diseases that comprise the greatest threat to St. Kitts' Orbicella spp., and the extent of their impact, are unknown.

Preliminary surveys of Orbicella spp. in St. Kitts in 2015 showed several lesion appearances. In order to guide future diagnostic investigations towards priority lesions with the greatest impact on the coral host, we systematically described macroscopic morphologic lesions of $O$. annularis and $O$. faveolata in the shallow $(<6 \mathrm{~m})$ fringing reefs of St. Kitts and compared differences in prevalence and progression among lesion categories. Furthermore, we identified morphological characteristics predictive of lesion progression.

\section{MATERIALS AND METHODS}

This study evaluated Orbicella annularis and $O$. faveolata organisms across 6 shallow fringing reefs along the north, east, southeast, and southwest peninsular shores of St. Kitts, including Turtle Beach, Reggae Beach, White House Bay, Major's Bay, Marriott Reef, and Dieppe Bay (Fig. 1). These sites were selected based upon proximity of reefs to shore access, depth $<6 \mathrm{~m}$, and the presence of $O$. annularis and $O$. faveolata. Because of its low prevalence in these study sites, O. franksi was not included. Two study designs were utilized, cross-sectional and longitudinal, to evaluate the prevalence of disease and lesion changes over time, respectively.

\subsection{Lesion categories based on morphology}

Most animal diseases cannot be diagnosed by macroscopic examination alone (Work \& Meteyer 2014). Therefore, the present study followed the standardized biomedical approach to disease investigation, in which abnormalities of corals were grouped according to morphological diagnoses (i.e. lesion category; Work \& Aeby 2006) rather than a presumptive disease name. Eight main lesion morphologies were consistently observed affecting Orbicella spp. during preliminary survey of shallow fringing reefs in St. Kitts in 2015 (Fig. 2, Table 1).

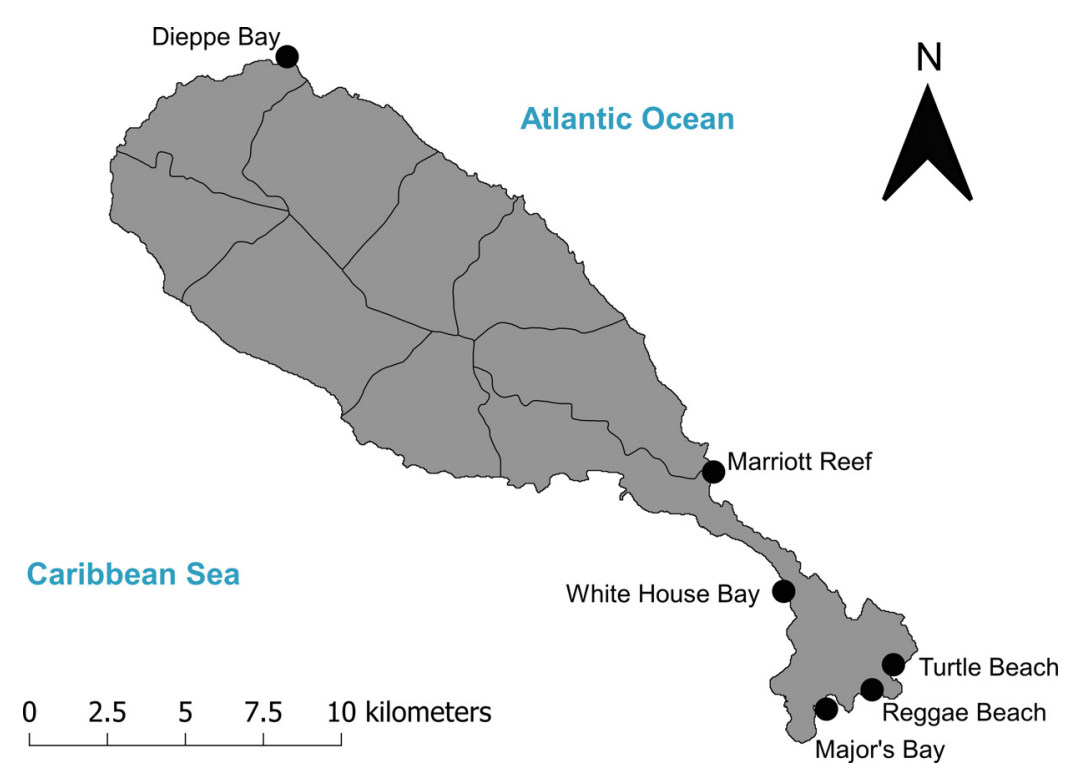

Fig. 1. Location of reefs surveyed for lesioned Orbicella spp. in St. Kitts. Corals were tagged at these sites and longitudinally assessed for lesion progression from August 2016-June 2017 


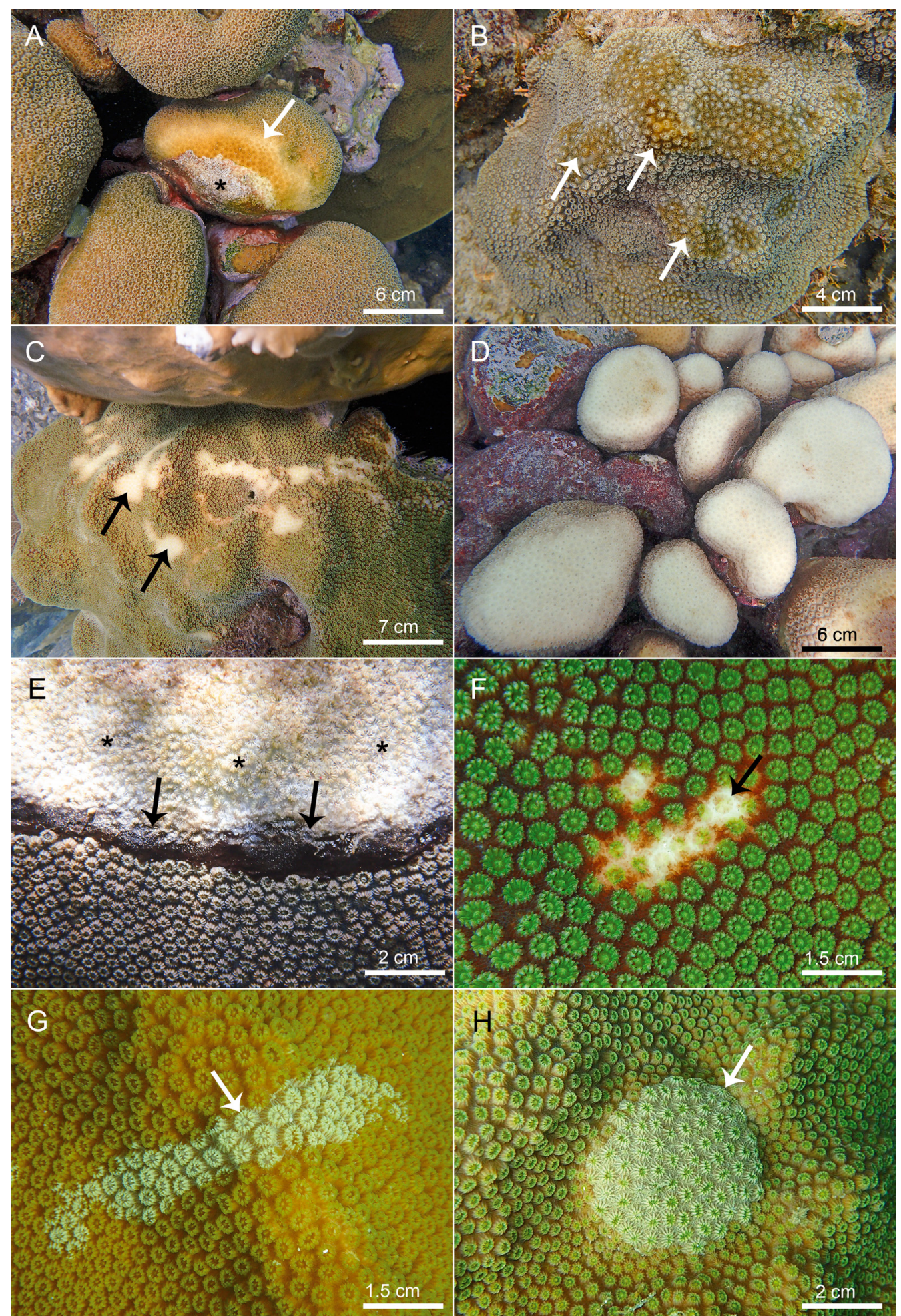

Fig. 2. Examples of lesion categories affecting Orbicella annularis (OA) and O. faveolata (OF) in shallow fringing reefs of St. Kitts. (A) Category 1: annular yellow to brown pigmentation (arrow) with chronic tissue loss (asterisk) in OA at Turtle Beach; (B) Category 2: focal brown pigmentation (arrows) in OF at Turtle Beach; (C) Category 3: focal bleaching (arrows) in OF at White House Bay; (D) Category 4: diffuse bleaching in OA at Turtle Beach; (E) Category 5: annular black surface deposit (arrows) with acute to chronic tissue loss (asterisks) in OF at Dieppe Bay; (F) Category 6: focal acute tissue loss with skeletal erosion (arrow) in OF at White House Bay; (G) Category 7: multifocal grey pigmentation (arrow) in OF at Major's Bay; and (H) Category 8: growth anomaly (arrow) in OF at Major's Bay 


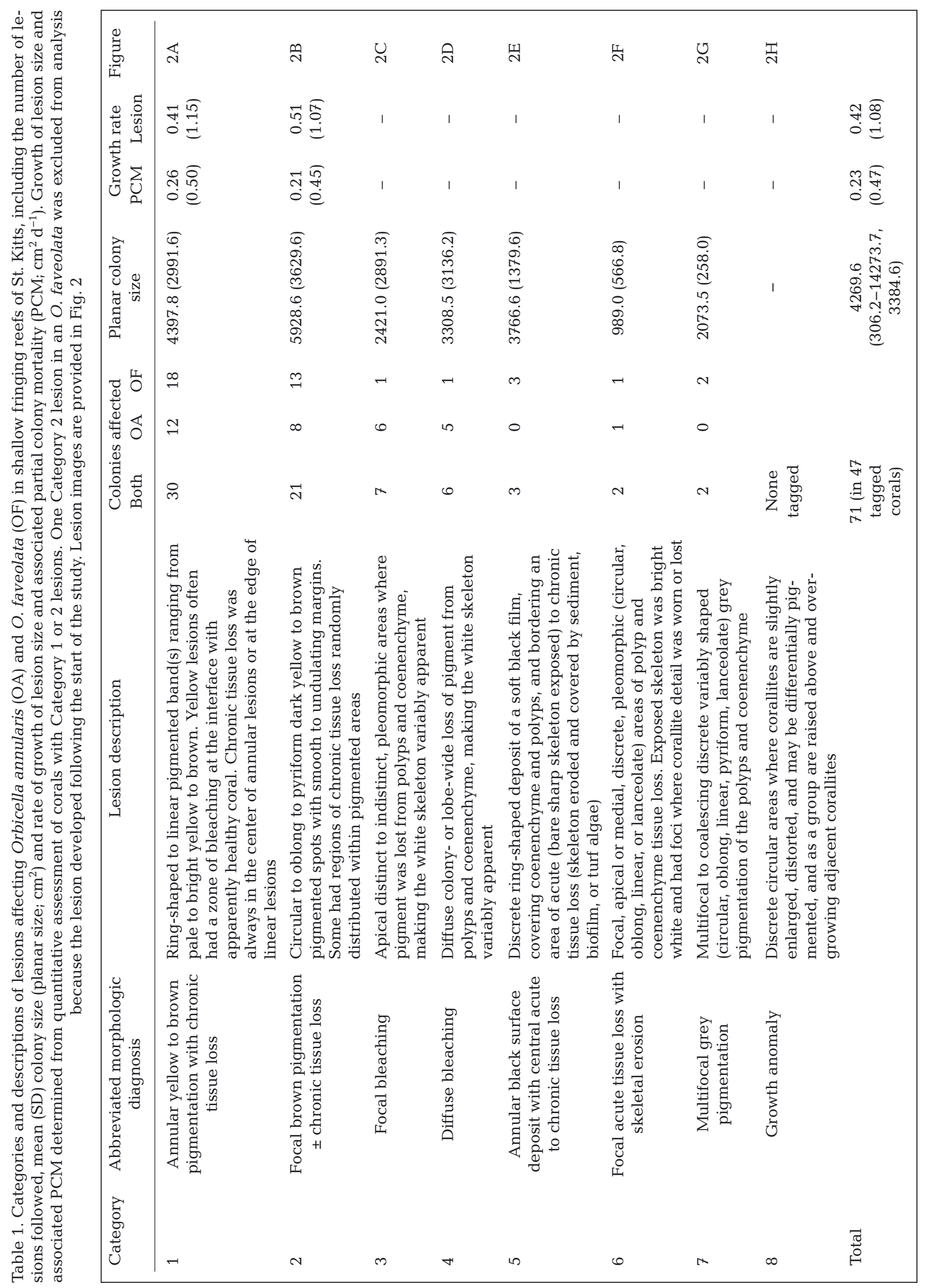


Category 1 lesions consisted of annular yellow to brown pigmentation with chronic tissue loss, evident by an annular yellow to brown pigmented area that marginated or surrounded a central area of chronic tissue loss (Fig. 2A). The area of chronic tissue loss had denuded skeleton that was covered in sediment and colonized by other organisms, particularly turf algae.

Category 2 lesions consisted of focal brown pigmentation \pm chronic tissue loss. These were nonring-shaped areas of brown pigmentation (Fig. 2B). Chronic tissue loss within these lesions was not confined to the central location of the ring of pigmentation, as seen in brown Category 1 lesions.

Category 3 lesions consisted of focal bleaching. These were evident as focal pigment loss that imparted translucency of the coral tissue, such that the skeleton was visibly apparent (Fig. 2C).

Category 4 lesions consisted of diffuse bleaching and were morphologically similar to Category 3 lesions, except that the entire coral or lobe of the coral was affected by pigment loss (Fig. 2D).

Category 5 lesions comprised annular black surface deposit with acute to chronic tissue loss. These were recognized by a ring-shaped band of a thin black film coating the coral surface at the margin of an area of tissue loss (Fig. 2E).

Category 6 lesions consisted of focal acute tissue loss with skeletal erosion. These were recognized by bright white denuded skeleton with sharp costal detail unobscured by sediment or algae, and a depressed surface where skeleton was lost and deep polyp anatomy was exposed (Fig. 2F).

Category 7 lesions consisted of multifocal grey pigmentation and were recognized by areas where polyps and coenenchyme were whitish-grey relative to unaffected tissue (Fig. 2G).

Category 8 lesions were growth anomalies. These lesions appeared as discrete groups of disfigured corallites, raised above and slightly extending over or crowding and compressing adjacent corallites (Fig. 2H). The corallites comprising the lesion were often slightly enlarged, distorted (flattened costa, collapsed septae or calices), and differentially pigmented compared to neighboring corallites.

Category 9 lesions included any other lesions not already categorized, including acute tissue loss (without skeletal erosion), clusters of disfigured corallites, and other pigmentations involving coloration other than yellow, brown or grey. In contrast to Category 8 lesions, clusters of disfigured corallites in Category 9 lesions were not raised or compressing adjacent corallites.

Images representing each category were compiled from preliminary surveys in St. Kitts in 2015. Observers, conducting cross-sectional surveys (see Section 2.3) together, reviewed these images prior to the surveys in order to reduce intra-operator variability in lesion classification.

\subsection{Longitudinal surveys for lesion progression}

A total of 470 . annularis $(\mathrm{n}=18)$ and $O$. faveolata ( $n=29$ ) representing all study reefs were included in the lesion progression surveys if the colony had macroscopic lesions representative of those commonly observed in St. Kitts' Orbicella spp. (Table 2, Fig. 2A-G). Divers tagged selected corals with large, bright-colored livestock ear tags. The tags were attached with cable ties or masonry nails to non-living substrate close to the colony.

The lesions of tagged corals were comprehensively described upon presentation and assigned to a lesion category based on gross morphological diagnosis (Work \& Aeby 2006) (Table 1). Lesion size was categorized by the widest dimension (diameter if roundish, length if linear) as small $(<2 \mathrm{~cm})$, medium $(2-8 \mathrm{~cm})$, or large $(>8 \mathrm{~cm})$. Lesion severity was categorized based on the approximate percent of the living colony tissue that was affected by the lesion at the start of the study: either mild (1-20\%), moderate (21-50\%), or severe (51-100\%).

Photographs (Olympus Tough TG-4 camera) and GPS coordinates (Garmin GPSmap 78SC) were taken of each tagged coral. GPS coordinates were plotted on maps, and laminated maps and photographs of tagged corals were used to facilitate subsequent identification of tagged corals. For corals that were

Table 2. Location, planar coral size (max. diameter and height), and depth of tagged Orbicella spp. corals (OA: O. annularis; OF: O. faveolata) monitored at 2-3 wk intervals for lesion progression in St. Kitts from August 2016-June 2017

\begin{tabular}{|c|c|c|c|c|c|}
\hline \multirow[t]{2}{*}{ Location } & \multicolumn{3}{|c|}{ Number of corals tagged } & \multirow{2}{*}{$\begin{array}{l}\text { Mean (SD) } \\
\text { depth (m) }\end{array}$} & \multirow{2}{*}{$\begin{array}{l}\text { Mean }(\mathrm{SD}) \text { planar } \\
\text { colony size }\left(\mathrm{cm}^{2}\right)\end{array}$} \\
\hline & Both & OA & $\mathrm{OF}$ & & \\
\hline Dieppe Bay & 16 & 9 & 7 & $1.1(0.25)$ & $5028.2(3868.2)$ \\
\hline Major's Bay & 7 & 3 & 4 & $2.2(0.31)$ & $5394.9(3275.7)$ \\
\hline Marriott Reef & 6 & 0 & 6 & $2.5(1.2)$ & 3539.9 (2373.3) \\
\hline Reggae Beach & 5 & 0 & 5 & $1.6(0.05)$ & $1987.6(1011.2)$ \\
\hline Turtle Beach & 8 & 3 & 5 & $2.0(0.44)$ & $5777.5(3003.4)$ \\
\hline White House Bay & 5 & 3 & 2 & $3.1(0.52)$ & $153.4(1042.6)$ \\
\hline Total & 47 & 18 & 29 & $1.9(0.85)$ & $4269.6(3306.2)$ \\
\hline
\end{tabular}


affected by multifocal lesions of the same category, a single representative lesion was selected to follow over the course of the study. Of corals that exhibited more than one lesion category, representative lesions of the predominating lesion category (no more than 2 $\mathrm{coral}^{-1}$ ) were followed. For each lesion followed, laminated examples of photographs to be reproduced over the study were used to guide snorkelers. The tagged colonies were monitored for up to 9 mo (August 2016-May 2017) at 2-3 wk intervals.

Planar coral size (maximum diameter and height) and percent colony mortality were estimated from colony photographs using a size reference and 'coral point count with Excel extensions' (CPCe) software (Kohler \& Gill 2006). The overall progression for each lesion was quantitatively assessed on lesions of Categories 1, 2, 5, and 6, using CPCe software and the initial and last photograph of each lesion (Kohler \& Gill 2006). The lesion size at its first encounter was the surface area of the lesion excluding any adjacent partial colony mortality (PCM). At the last encounter, the lesion size was the surface area of the lesion including any new adjacent PCM that had developed since the first encounter. Lesions were assigned to an overall lesion progression category: progressing (lesion growing in size, or lesion unchanged in size but with a growing area of PCM within it), quiescent (no significant change), or regressing (i.e. lesion or area of adjacent colony mortality shrinking in size or resolved, but potentially leaving an area of PCM). Lesion growth rate $\left(\mathrm{cm}^{2} \mathrm{~d}^{-1}\right)$ was defined as the difference in size between the first and last observation divided by the follow-up time. PCM growth rate $\left(\mathrm{cm}^{2} \mathrm{~d}^{-1}\right)$ was calculated on the same principle using the size of dead tissue at the first and last observations. Categories of lesion progression severity were defined using PCM growth as follows: first category included the corals with regression of PCM growth. Second, third, and fourth categories (mild, moderate, and severe) were based on the 0.33 and 0.66 quantile of the variable (negative values excluded, quiescent lesions included).

Predictors of severity were identified by using a cumulative link mixed model ('clmm' function in the 'ordinal' package in R; R Core Team 2017, Christensen 2019) with the created severity variable as ordinal outcome and coral numbers as random variables. Type of lesion, size of the lesion at the beginning, lesion progression, presence of Category 3 or 4 (bleached) lesions, bleached margin accompanying Category 1 lesions (brown vs. yellow color), and presence of distinct margins were tested as predictors of severity in univariate models.
Daily sea surface temperature averages for St. Kitts were used to examine the relationship between temperature and bleaching and were sourced from the International Comprehensive Ocean-Atmosphere Data Set (ICOADS) Release 3 (Freeman et al. 2017) using $17-18^{\circ} \mathrm{N}$ as latitude and $63-62^{\circ} \mathrm{W}$ as longitude limits.

\subsection{Cross-sectional surveys for lesion prevalence}

In the spring of 2017 (March-June), $1 \mathrm{~h}$ timed swims were undertaken by 3 to 4 observers, once at each of the 6 sites. A total of 3 observers surveyed Turtle Beach, Reggae Beach, White House Bay, Marriott Reef, and Dieppe Bay, and 4 surveyed Major's Bay (Fig. 1). Surveys were only undertaken when visibility was $>10 \mathrm{~m}$. Each observer separately surveyed the reef via snorkeling, generally swimming together but $>5 \mathrm{~m}$ apart to ensure that separate data were recorded. The swims had a pattern which followed the reef contour longitudinally and covered approximately $0.5 \mathrm{~km}$ of reef (resulting in about $1.5-2 \mathrm{~km}$ surveyed reef $^{-1}$ ). Where a reef had a prominent reef crest, surveys were focused on the back reef, where the target species were common. Observers identified $O$. annularis and $O$. faveolata colonies within $\sim 2.5-3 \mathrm{~m}$ of either side of the observer and recorded the health status of each. Corals were categorized as 'unaffected' (i.e. apparently healthy) if no lesions were seen or as 'diseased' if one or more macroscopic lesions were identified.

For data analyses, each observer swim was considered an individual cross-sectional survey. In order to reduce any observer effect on lesion data, the prevalence and SE of coral lesions were calculated for each observer for each site and across all sites. Weighting for each observer was defined as the inverse of the variance $\left(1 / \mathrm{SE}^{2}\right)$. If an observer did not see any lesions or noted only diseased corals, prevalence was adjusted by adding 0.5 to the number of diseased corals $(\mathrm{d}+0.5)$ and 1 to the number of observed corals ( +1 ; Higgins \& Green 2011, Lee et al. 2016). Weighted means of coral lesions (adjusted mean prevalence, AMP) and 95\% CIs were calculated for both species over all 6 locations, then by coral species, location, and lesion category. When calculating the AMP of lesions, all lesion categories were included, whereas when calculating AMP of disease, all lesion categories were pooled except for Categories 3 and 4 (focal and diffuse bleaching) and 6 (focal tissue loss with skeletal erosion). For visualization, error plots of the AMP of lesions and disease with their 95\% CIs were made. 


\section{RESULTS}

\subsection{Lesion morphology and progression}

A total of 47 corals showing one or more of the lesion morphologies categorized in Section 2.1 were tagged. The morphological features of 72 lesions were described in detail, and their lesion progression monitored over the course of the longitudinal surveys. Of the 47 tagged corals, $23(48.9 \%)$ had more than one lesion category at some point during the study, including 8/23 with Category 1 and 2 lesions, 2/23 with Category 1 and 2 plus bleaching (Categories 3 or 4), $6 / 23$ with Category 1 plus bleaching (Categories 3 or 4), 2/23 with Category 2 plus bleaching (Categories 3 or 4$), 2 / 23$ with Category 6 and bleaching (Categories 3 or 4), 2/23 with Category 1 and 5, and 1/23 with Categories 1, 2, and 5. Twelve of the 23 (52.2\%) tagged corals affected by multiple lesion categories were Orbicella annularis and $11(47.8 \%)$ were $O$. faveolata. For morphological descriptions, lesion attributes focused on the entirety of the lesion (i.e. including multiple foci), whereas lesion progression was assessed in one focal area of the lesion.

Quantitative lesion progression analysis was performed on Category 1 and 2 lesions, including 52 lesions from 42 corals. One Category 2 lesion appeared in an $O$. faveolata after the corals were tagged and was excluded from further analyses to avoid bias in the regression analyses. Quantiles of positive (increasing) PCM were 0.07 (33\%) and 0.29 (67\%). The severity was then classified as regression (PCM $\leq 0$; $\mathrm{n}=18)$, mild ( $\mathrm{PCM}=0-0.1 ; \mathrm{n}=14)$, moderate $(\mathrm{PCM}=$ $0.1-0.3 ; n=8)$, and severe $(\mathrm{PCM}>0.3 ; \mathrm{n}=11)$.

\subsubsection{Category 1: annular yellow to brown pigmentation with chronic tissue loss}

In total, 30 Category 1 lesions (Fig. 2A) were assessed in 47 tagged corals (Table 3). The pigmented area varied from pale to bright yellow $(18 / 30,60 \%)$, or tan to brown $(12 / 30,40 \%)$. Some of the corals with yellow lesions $(5 / 18,27.7 \%)$ had a marginal band of bleaching between the pigmented band and apparently healthy tissue (Fig. 2A). Of the 30 tagged Category 1 lesions, $19(63.3 \%)$ were progressing, 2 (6.7\%) were quiescent, and $9(30.0 \%)$ were regressing (Fig. 3). Progression ranged from mild (7/19, 36.8\%) to moderate $(5 / 19,26.3 \%)$ or severe $(7 / 19,36.8 \%)$. Progression severity was increasing when lesions had a marginating zone of bleaching (ordinal odds ratio [OOR] from the cumulative link mixed model:

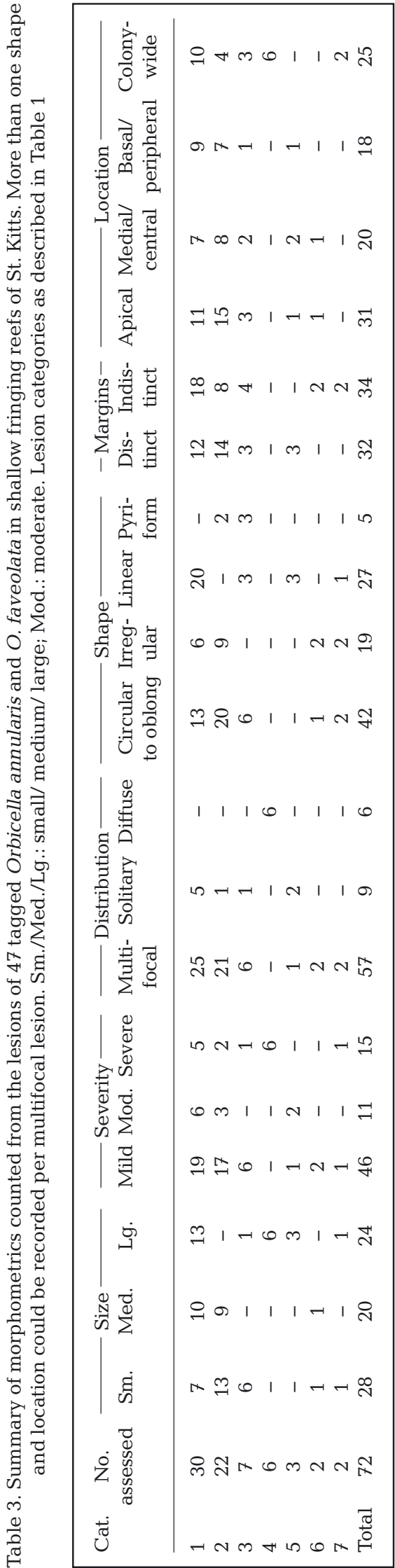




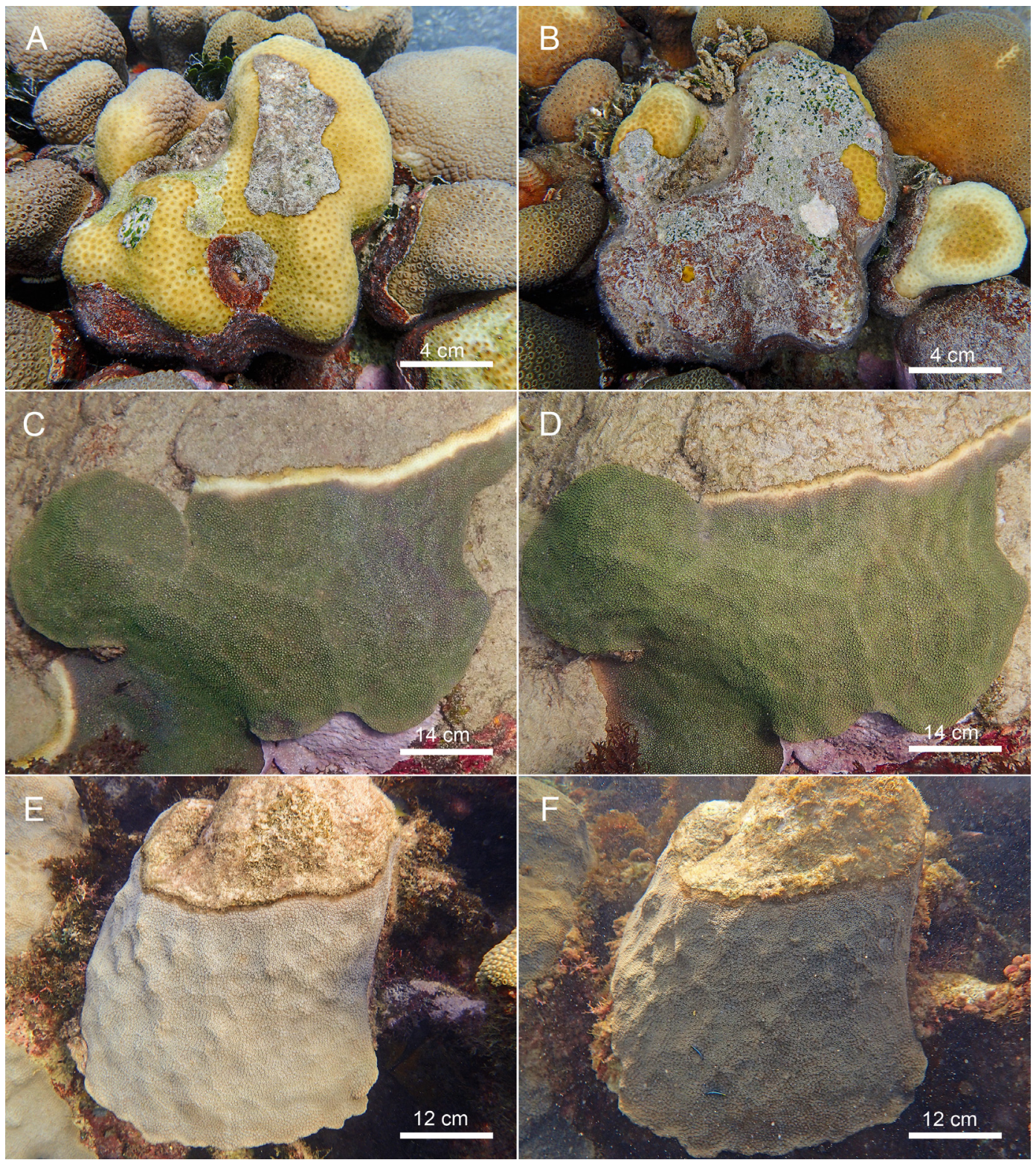

Fig. 3. Progression of Category 1 lesions (annular yellow to brown pigmentation with chronic tissue loss). Orbicella annularis at Turtle beach classified as having severe progression, i.e. percent colony mortality >0.3, in (A) November 2016 and (B) May 2017. $O$. faveolata at Marriott Reef classified as having moderate progression, i.e. percent colony mortality $=0.1-0.3$, in $(\mathrm{C})$ September 2016 and (D) February 2017. O. faveolata at Marriott Reef showing quiescence, i.e. no change in percent colony mortality, in (E) September 2016 and (F) June 2017. Scale bars are provided in each image

11.0; 95\% CI: 1.3-92.7; Figs. 2A \& 3C). Lesions with yellow color had a more severe progression than those with brown color (OOR: 3.8; 95\% CI: 1.5-9.7). Two lesions (one each in O. annularis and $O$. faveolata) were classified as having mild progression and initially started as yellow but turned a dark brown over the course of the study. Distinct margins and thickness of the yellow/brown band were not predictors of severity (OOR: 2.7; 95\% CI: $0.6-12.9$ and 2.4 [0.8-7.2], respectively).
Quiescence was only observed in 2 corals. One $O$. faveolata exhibited a distinct dark brown annular band surrounding a large area of PCM (Fig. 3E,F). The other was an $O$. annularis that showed a paler brown indistinct band at the base of the colony which marginated an area of PCM. Neither location, intensity, nor colors of these bands changed over the study period.

Regression was observed in 3 O. faveolata and $6 O$. annularis, across 4 different reefs (Dieppe Bay, Major's 
Bay, Reggae Beach, and Turtle Beach). In 4/9 (44.4\%) cases the pigmented band was brown whereas the others were yellow. Three $O$. annularis initially had yellow lesions that were either faded/reduced or absent by the end of the study and PCM had decreased by $5-14 \mathrm{~cm}^{2}$. Three $O$. faveolata and one $O$. annularis had brown lesions with centers of PCM that decreased in size by $1-16 \mathrm{~cm}^{2}$ over the course of the study, and in 2 affected corals the brown pigmentation lessened over time.

\subsubsection{Category 2: focal brown pigmentation \pm chronic tissue loss}

Category 2 lesions (Fig. 2B) were assessed in 22 of the 47 tagged corals (Table 3 ). Chronic tissue loss was observed in 9/22 (40.9\%) Category 2 lesions. Thirteen of 22 (59.1\%) Category 2 lesions had tightly closed polyps and prominently flattened to collapsed costae, and some $(9 / 22,40.9 \%)$ had swollen polyps. Two of $22(9.1 \%)$ Category 2 lesions had a depressed center.

Of the 21 Category 2 lesions that were quantitatively assessed for mortality progression, 14 (66.7\%) were progressing, $4(19.0 \%)$ were quiescent, and 3 $(14.3 \%)$ were regressing (Fig. 4). Progression ranged from mild $(7 / 14,50.0 \%)$ to moderate $(3 / 14,21.4 \%)$ or severe $(4 / 14,28.6 \%)$. Distinct margins and intensity of brown color were not predictive of progression severity (OOR: 2.7; 95\% CI: $0.6-12.9$ and 0.8 [0.18.2], respectively).

Quiescence was observed in 4 Category 2 lesions, including $2 \mathrm{O}$. annularis and $2 \mathrm{O}$. faveolata from 3 reefs (Dieppe Bay, Major's Bay, and Turtle Beach). Two of these lesions were intense dark brown with distinct margins, and 2 were pale brown-yellow with indistinct margins. Regression was observed in 2 O. faveolata and one O. annularis, across 2 different reefs (Turtle Beach and Marriott Reef). All initially had fairly well-defined brown spots of moderate to marked intensity. The $O$. annularis had numerous poorly defined pale brown foci in September, and by May the foci had increased in number and intense dark brown, yet PCM had marginally decreased by $9 \mathrm{~cm}^{2}$. One $O$. faveolata had intense dark spots initially, but these had faded and were poorly defined by May while PCM was also marginally decreased by $8 \mathrm{~cm}^{2}$. Another $O$. faveolata had poorly defined spots and small areas of PCM initially, and by May the spots had become darker while the areas of PCM resolved by $7 \mathrm{~cm}^{2}$.

\subsubsection{Categories 3 and 4 : focal and diffuse bleaching}

In total, 7 Category 3 and 6 Category 4 lesions (Fig. $2 \mathrm{C}, \mathrm{D}$ ) were assessed among the 47 tagged corals (Table 3, Fig. 5). For Category 4 lesions, bleaching was always diffuse, but unevenly distributed, typically more severe apically than basally.

The progression of focal and diffuse bleaching was similar. Although not examined statistically, lesion progression followed sea surface temperature, becoming more severe with increasing temperature and sustained high temperatures and resolving within 1-2 mo after temperature decreased (Figs. 5 \& 6). Bleaching lesions were at their most severe in either October $(1 / 13,7.7 \%)$, November $(10 / 13,76.9 \%)$, or December $(2 / 13,15.4 \%)$. A small $O$. annularis with multifocal bleaching for $5 \mathrm{wk}$ progressed to acute tissue loss (polyps and coenenchyme) in all bleached foci in December, had recovered from bleaching by May, but had a 5\% increase in PCM by the end of the study. Tagged corals with Category 3 or 4 lesions also had Category 1 (9/13; Fig. 5C-F), Category 2 $(2 / 13)$, or Category $6(1 / 13)$ lesions. Category 1 lesions showed severe progression synchronous with bleaching and after the bleaching recovered in 3/9 affected corals. Otherwise, no relationship between bleaching status and progression of other lesions was observed. Other than the categories of lesions concurrently affecting tagged bleached corals at the start of the study, no new lesions developed during/ following bleaching.

\subsubsection{Category 5: annular black surface deposit with acute to chronic tissue loss}

A total of 3 Category 5 lesions (Fig. 2E) were assessed among the 47 tagged corals, only one of which was present at the start of the study. One of $3(33.3 \%)$ had white areas in the surface film. The widths of the bands were uneven and ranged from 1-5 polyps wide. In 2 corals, the exposed skeleton in the central area of tissue loss was covered by algae (oldest standing area of lesion), whereas the exposed skeleton at the edges of the area of tissue loss was covered by a thin layer of sediment, biofilm, or turf algae (less old area of lesion), and the exposed skeleton at the interface with the black film was bright white and had sharp, non-eroded costal detail unobscured by sediment or algae (newest area of the lesion). The intact coral tissue adjacent to the black film appeared grossly normal in all lesions (Figs. 2E \& 7A-C). 


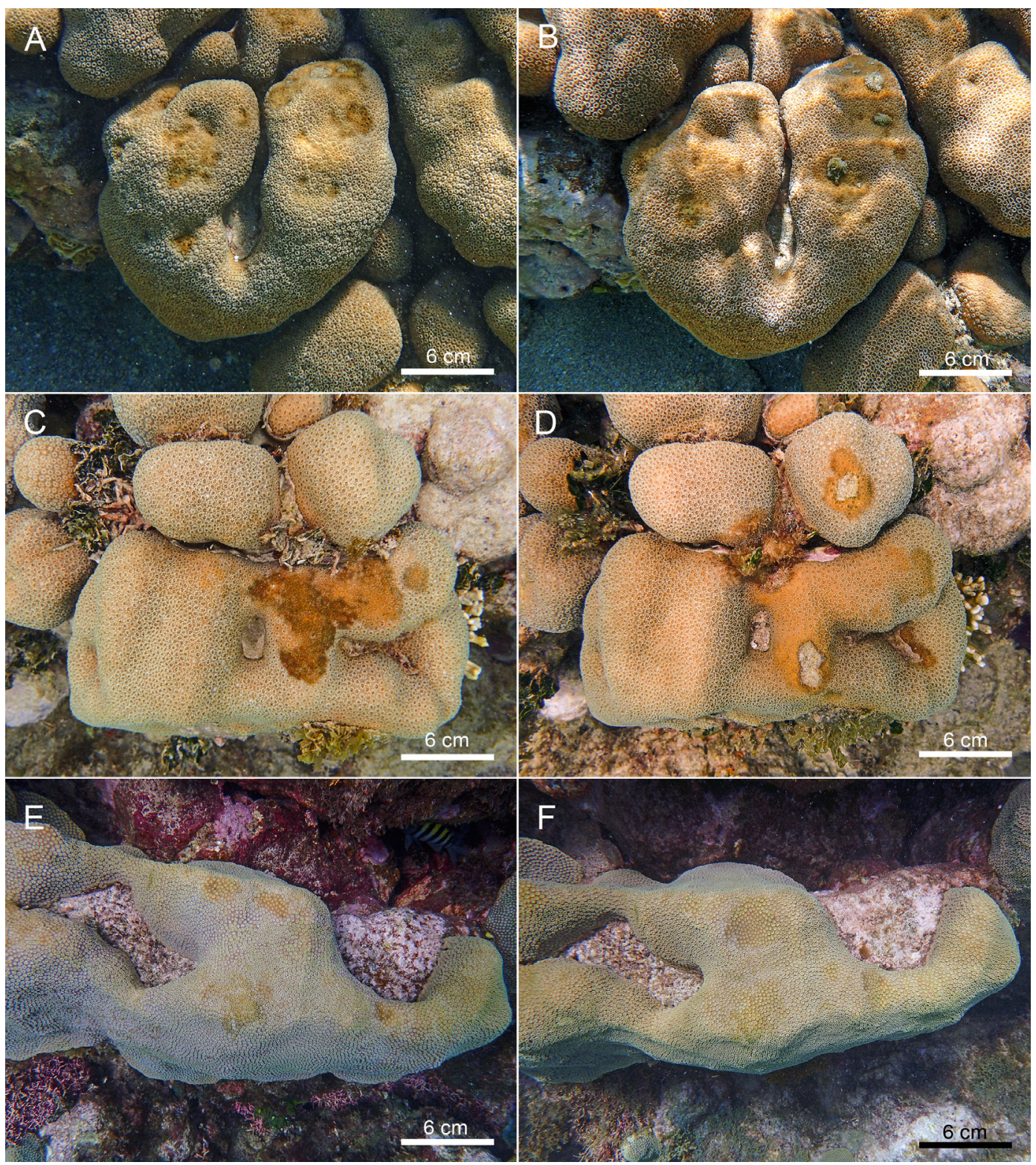

Fig. 4. Progression of Category 2 lesions (focal brown pigmentation with chronic tissue loss). Orbicella annularis at Dieppe Bay classified as having mild progression, i.e. percent colony mortality $=0-0.1$, in (A) September 2016 and (B) June 2017. O. annularis at Turtle Beach classified as having moderate progression, i.e. percent colony mortality $=0.1-0.3$, in (C) February 2017 and (D) May 2017. O. faveolata at Turtle Beach showing quiescence, i.e. no change in percent colony mortality, in (E) September 2016 and (F) May 2017. Scale bars are provided in each image

Three Category 5 lesions (annular black surface deposit with acute to chronic tissue loss) in 3 corals were tracked in this study. One was evident at the beginning of the study and 2 developed towards the end of the study when sea surface temperatures started to rise again. Although not assessed quantitatively, these lesions were characterized by rapid progression of acute tissue loss (Fig. 7A-C), followed by loss of the black surface deposit (coinciding with decreasing sea surface temperature) and subsequent remis- sion (i.e. tissue loss ceased once the surface deposit was lost).

\subsubsection{Category 6: focal acute tissue loss with skeletal erosion}

Category 6 lesions (Fig. 2F) were assessed in 2 of the 47 tagged corals. Both Category 6 lesions healed completely within weeks. 


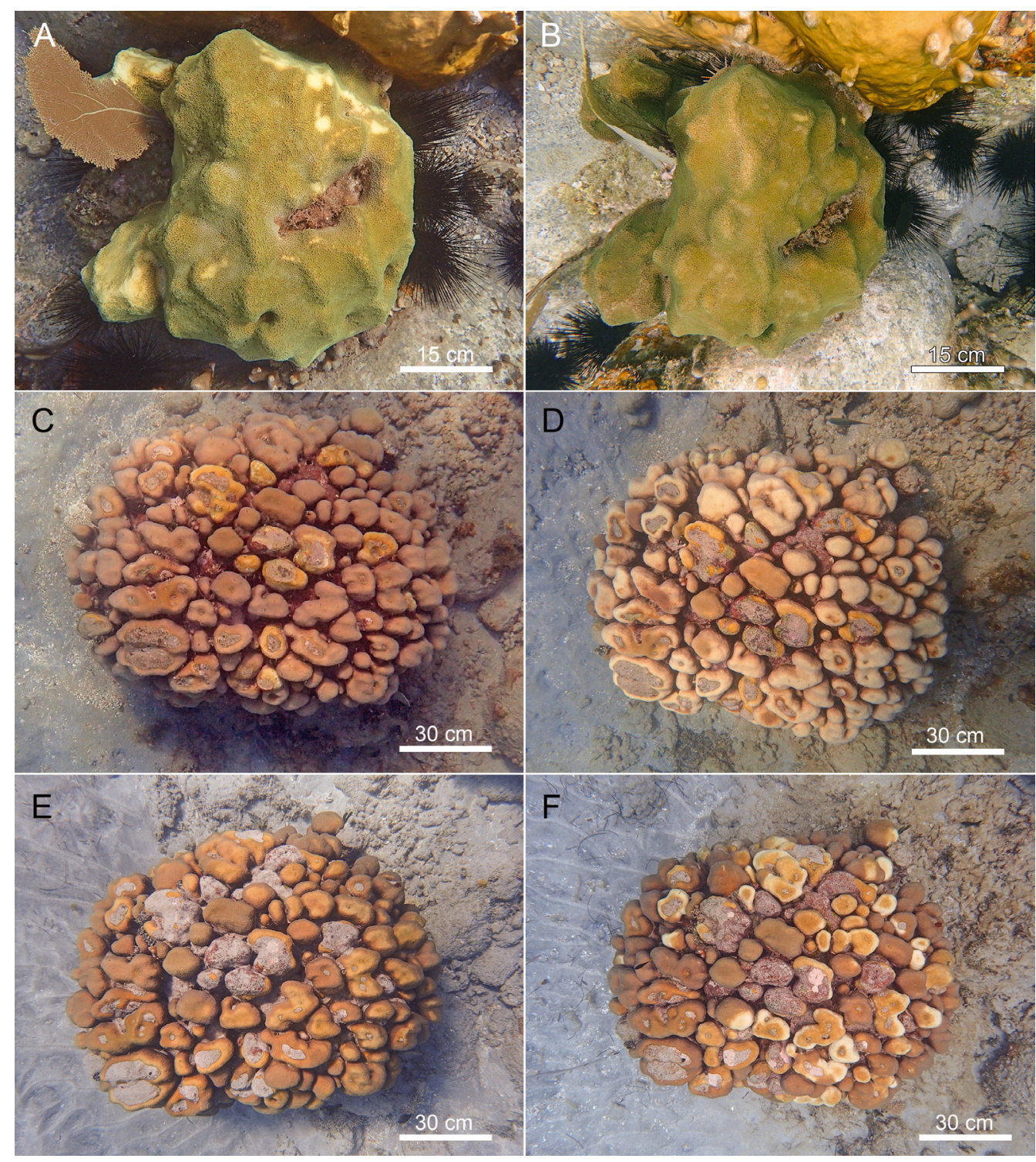

Fig. 5. Category 3 (focal bleaching) and 4 (diffuse bleaching) lesions. Orbicella faveolata at White House Bay at (A) peak severity in November 2016 and (B) recovered in May 2017. O. annularis at Turtle Beach showing progression of a Category 4 lesion (diffuse bleaching) and concurrent severe progression of Category 1 lesions (annular yellow to brown pigmentation with chronic tissue loss) in (C) September 2016, (D) November 2016, (E) March 2017, and (F) May 2017. Scale bars are provided in each image

\subsubsection{Category 7: multifocal grey pigmentation}

Among the 47 tagged corals, 2 Category 7 lesions (Fig. 2G) were assessed. Both were quiescent (i.e. unchanging) for the entire length of the study (Fig. 7D,E).

\subsection{Lesion prevalence}

A total of $912 O$. annularis $(\mathrm{n}=223)$ and $O$. faveolata $(\mathrm{n}=689)$ colonies were counted in 6 shallow fringing reefs during cross-sectional surveys in St. Kitts. The overall AMP of lesions was 59.0\% (95\% CI: $55.8-62.1 \%$ ), and disease prevalence (i.e. excluding Categories 3, 4, and 6) was $46.9 \%$ (95\% CI: $43.7-$ $50.1 \%)$. Category $1(22.9 \%$; $95 \%$ CI: $20.2-25.6 \%)$ and $2(23.1 \%$; 95\% CI: $20.4-25.8 \%)$ lesions were most common and were equally prevalent overall (Fig. 8A). In contrast, Category 8 lesions were uncommon (0.4\%; 95\% CI: $0.0-0.9 \%)$ and were only observed affecting $O$. faveolata, but they were observed at all reefs apart from White House Bay. Category 6 lesions 


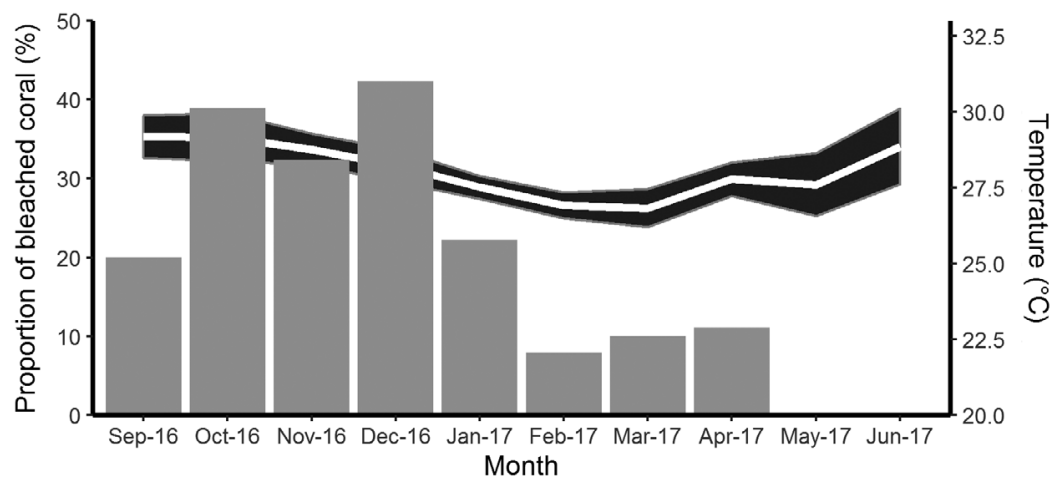

Fig. 6. Monthly mean sea surface temperature (white line) with 95\% CI (black shaded band) and proportion of 47 tagged corals showing diffuse or focal bleaching (no. of assessments $=287$ ) in St. Kitts each month (bars) from September 2016-June 2017
$46.7 \%$; 95\% CI: $43.0-50.4 \%$, respectively). Disease prevalence also varied by location (Fig. 8B-D) and was highest at Dieppe Bay $(58.4 \%$; 95\% CI: $52.0-64.9 \%$ ), and lowest at White House Bay $(23.9 \%$; 95\% CI: 15.1$32.7 \%$ ). Category 1 lesions were most prevalent in $O$. annularis at Dieppe bay $(57.5 \%$; $95 \%$ CI: $45.2-69.9 \%$; Fig. 8C). Category 2 lesions were most prevalent among corals at Dieppe Bay and Marriott Reef $(30.7 \%$; 95\% CI: $24.7-36.6 \%$ and $34.7 \%$; $28.3-41.2 \%$, respectively; Fig. 8D).

\section{DISCUSSION}

were much more common among $O$. annularis $(22.7 \%$; 95\% CI: $17.3-28.1 \%)$ relative to O. faveolata $(4.4 \%$; 95\% CI: $2.9-5.8 \%$ ).

Lesion and disease prevalence were generally higher in O. annularis $(69.9 \%$; 95\% CI: 64.3-75.6\% and $43.3 \%$; $95 \% \mathrm{CI}: 37.1-49.4 \%$, respectively) relative to O. faveolata $(55.2 \%$; 95\% CI: $51.5-58.9 \%$ and
St. Kitts and Nevis' reef health index was recently scored the lowest of 6 Eastern Caribbean nations (Kramer et al. 2016). In that report, it was indicated that the country's Orbicella spp. were 'on the tipping point of recovery or decline' (Kramer et al. 2016, p. 4).

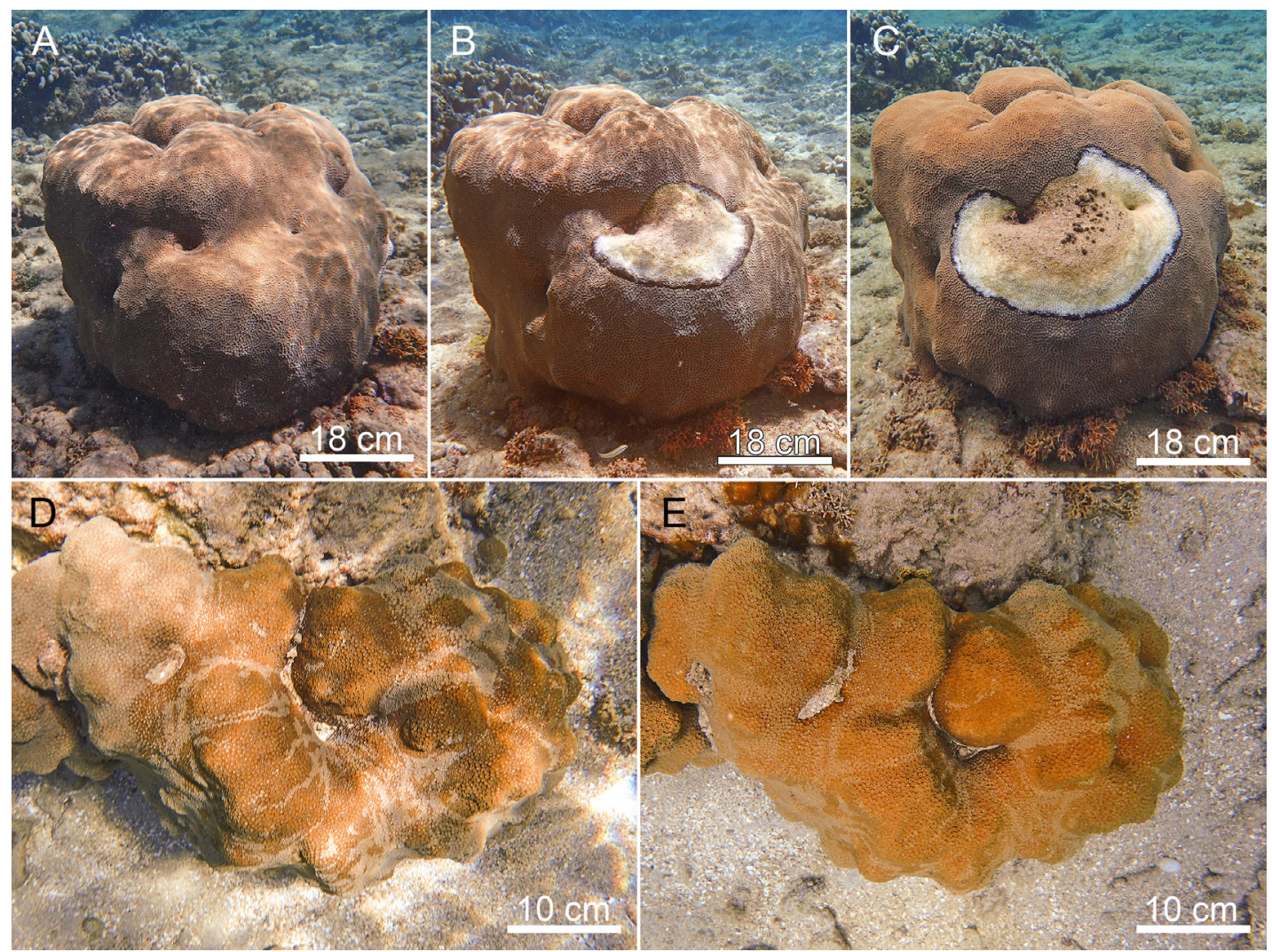

Fig. 7. Orbicella faveolata at Dieppe Bay showing severe progression of a Category 5 lesion (annular black surface deposit with acute to chronic tissue loss) in (A) September 2016, (B) May 2017, and (C) June 2017. O. faveolata from Dieppe Bay showing quiescence typical of a Category 7 lesion (Multifocal grey pigmentation) in (D) December 2016 and (E) June 2017. Scale bars are provided in each image 

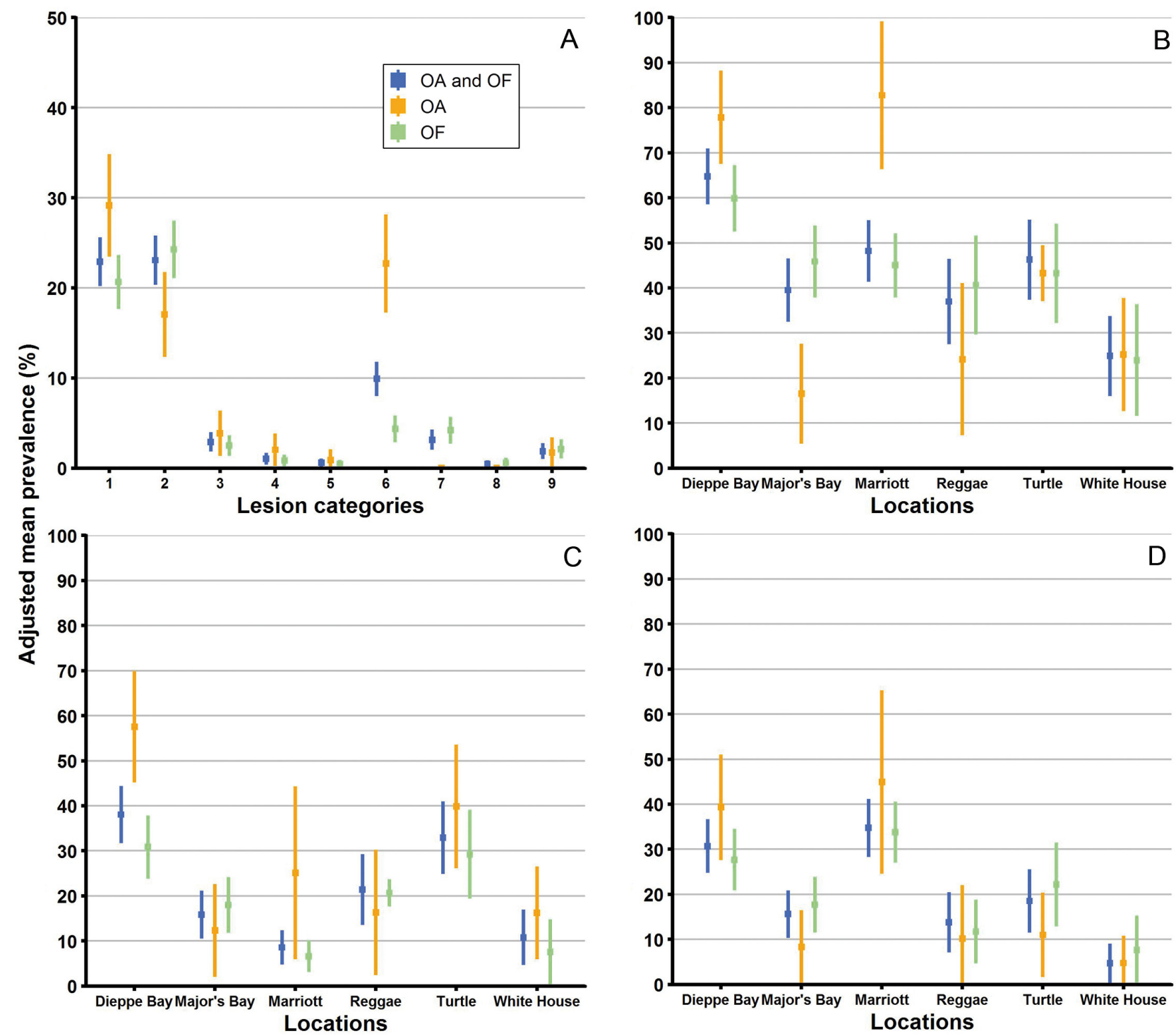

Fig. 8. (A) Adjusted mean prevalence (with 95\% CI) of each category of lesion at all locations, with comparison between Orbicella annularis $\left(\mathrm{OA}_{;} \mathrm{n}=223\right)$, O. faveolata $(\mathrm{OF} ; \mathrm{n}=689)$, and both grouped together $(\mathrm{n}=912)$. (B) Adjusted mean prevalence of disease (i.e. excluding lesion Categories 3-4 and 6, focal and diffuse bleaching, and multifocal tissue loss with skeletal erosion; $\mathrm{n}=428$ ). (C) Adjusted mean prevalence of Category 1 lesions only (annular yellow to brown pigmentation with chronic tissue loss; $\mathrm{n}=220$ ). (D) Adjusted mean prevalence of Category 2 lesions only (focal brown pigmentation with chronic tissue loss; $\mathrm{n}=217$ )

The present study suggests the latter, where disease is highly prevalent $(46.9 \%)$ and the loss of living coral tissue as a result of disease outpaces the rate of Orbicella spp. colony growth of $\sim 5-10 \mathrm{~mm}$ linear growth per year (Gladfelter et al. 1978). For example, within 9 mo, the mean $( \pm \mathrm{SD})$ rate of tissue loss due to just Category 1 or 2 lesions was $0.23 \pm 0.47 \mathrm{~cm}^{2} \mathrm{~d}^{-1}$. Other studies have also demonstrated high prevalence of disease (i.e. $>5 \%$ and as high as $18 \%$ ) in these species in the Bahamas, Bonaire, the Cayman Islands, Colombia, Puerto Rico, and Venezuela (Weil 2004, Bruckner 2012), as well as similar disease-associated increases in percent colony mortality in Orbicella spp. (Bruckner \&
Bruckner 2006b). Prevalence was much higher in the present study and higher than that observed in a survey of 25 reefs of St. Kitts in 2010, where prevalence of disease across all scleractinian coral species was 1.2\% (Bruckner \& Williams 2012). The high prevalence of disease in the present study may be biased by the shallow location of surveys, because $O$. annularis and $O$. faveolata are generally larger on shallow reefs than on deeper reefs, and several diseases may be more prevalent in larger corals (Santavy et al. 1999, Nugues 2002, Foley et al. 2005, Bruckner \& Bruckner 2006a,b, Bruckner 2012). Nonetheless, Orbicella spp. appear highly susceptible to disease, and the present 
impact on multi-century-old individuals suggests that disease is a recent problem for these species (Weil 2004, Bruckner 2012).

The overall AMP of disease and the prevalence of each major lesion category were similar in $O$. annularis and $O$. faveolata, suggesting that both species are similarly susceptible to disease. This finding is in concordance with others (Gil-Agudelo \& Garzón-Ferreira 2001, Weil 2004), and is not surprising as both species belong to the same genus and, until recently, they were even believed to be different morphotypes of the same species (Budd et al. 2012). In addition, they live in similar environments, and are therefore exposed to similar conditions and possibly etiologic agents.

Disease prevalence varied among study sites, being highest at Dieppe Bay (64.7\%; 58.6-70.9\%) and Marriott Reef $(48.2 \% ; 41.4-55.0 \%)$ and lowest at White House Bay (24.9\%; 16.0-33.8\%). These differences again likely reflect bias from depth and size-class distributions, because larger corals may be more prone to certain lesions (Nugues 2002, Foley et al. 2005, Bruckner \& Bruckner 2006b, Bruckner 2012). In general, study locations with higher prevalence tended to comprise Atlantic areas that are exposed to the typical north-easterly winds and swells and are generally subjected to rougher seas (i.e. higher wave height, potentially associated with greater turbidity or fluctuations in other water quality parameters). There were no obvious differences in management or anthropogenic factors, such as reef use or coastal development, among study sites that would readily explain differential prevalence of disease. Future studies addressing water flow and quality factors might help explain differences in disease prevalence among study sites.

The present study categorized lesions according to morphological diagnosis rather than trying to diagnose a specific disease based on visual appearance. Corals with annular yellow to brown pigmentation with chronic tissue loss (Category 1 lesions in the present study) are often given a field diagnosis of yellow band disease (Raymundo et al. 2008, Bruckner \& Riegl 2016), and those with focal brown pigmentation \pm chronic tissue loss (Category 2 lesions in the present study) are often given a field diagnosis of dark spots disease (Raymundo et al. 2008). Orbicella spp. are known to be among the most susceptible corals to these diseases (Raymundo et al. 2008), and this is consistent with the findings in our study. Other diseases that Orbicella spp. are known to be susceptible to include white plague disease, stony coral tissue loss disease (SCTLD), black band disease, and growth anomalies (Sutherland et al. 2004, Aeby et al. 2019). Annular black surface deposit with acute to chronic tissue loss (Category 5 lesion in the present study) is a typical lesion of black band disease (Raymundo et al. 2008), although high intensity folliculinid ciliate infections may appear similar (Cróquer et al. 2006). This lesion was of low prevalence but was significantly impacting St. Kitts' Orbicella spp. Acute and rapidly progressing tissue loss, potentially given a field diagnosis of white plague (Raymundo et al. 2008) or SCTLD (Aeby et al. 2019), was rare among surveyed corals of the present study, but has been shown to cause significant mortality in Orbicella spp. elsewhere, for white plague particularly at greater depths than those assessed by the present study (Nugues 2002, Borger 2003, Bruckner \& Bruckner 2006b, Bruckner 2012).

Annular yellow to brown pigmented lesions (Category 1) had the greatest relative impact over the study period, with an AMP of $22.9 \%$ (95\% CI: 20.2$25.6 \%)$ and mean $( \pm \mathrm{SD})$ rate of associated PCM of $0.26 \pm 0.50 \mathrm{~cm}^{2} \mathrm{~d}^{-1}$. Substantial Orbicella spp. mortality has been attributed to similar lesions in other studies (Cervino et al. 2001, Foley et al. 2005, Bruckner \& Bruckner 2006a,b, Bruckner 2012). In the present study, these lesions affected $\sim 20 \%$ of corals, within the range reported for Orbicella spp. at similar depths (4-30\%) (Bruno et al. 2003, Foley et al. 2005). Linear lesion growth for similar lesions has ranged from 0.5-1.0 $\mathrm{cm} \mathrm{mo}^{-1}$ (Cervino et al. 2001, Bruno et al. 2003, Bruckner \& Bruckner 2006a), but it is difficult to compare to the rate of lesion growth measured by surface area in the present study. Morphological features associated with rapid progression of lesions in this category included yellow color and the presence of a bleached zone between the apparently healthy coral and the yellow pigment. While the bleached zone has been described since early reports of yellow band disease (Santavy et al. 1999), to the authors' knowledge it has not yet been associated with comparatively rapid progression rate. Yellow band disease has also been described to have yellow or brown pigmentation, where lesioned tissue may become darker yellow or brown before dying (Bruckner \& Bruckner 2006a). In the present study, brown pigmentation was associated with slower progression or quiescence of lesions. Of the 30 quantitatively assessed lesions, $11(36.7 \%)$ were quiescent or regressed during the study period. Other studies longitudinally following similar lesions have described remission (i.e. pigmentation no longer apparent) rates ranging from 7-32\% (Bruckner \& Bruckner 2006a,b). As there seems to be wide variability in the progression of these lesions, and corals are limited in the means by which they can manifest lesions, it is possible that the gross changes are not specific to a single disease pro- 
cess or etiology. Histopathological comparisons among annular pigmented lesions which progress at different rates would be informative from this regard.

Focal brown pigmentation with chronic tissue loss (Category 2) was also highly prevalent (AMP 23.1\%; $95 \%$ CI: $20.4-25.8 \%)$, and the mean $( \pm \mathrm{SD})$ rate of associated PCM $\left(0.21 \pm 0.45 \mathrm{~cm}^{2} \mathrm{~d}^{-1}\right)$ was at levels comparable to those reported in a survey of $O$. annularis (prevalence $=17.1 \%)$ and $O$. faveolata (prevalence $=$ $19.9 \%$ ) in the Colombian Caribbean (Gil-Agudelo \& Garzón-Ferreira 2001). Interestingly, other surveys including Orbicella spp. have failed to describe similar lesions (Cervino et al. 2001, Borger 2003, 2005). This may reflect differences in depth surveyed, as these lesions are more prevalent in Orbicella spp. at shallow depths (Gil-Agudelo \& Garzón-Ferreira 2001). In $O$. annularis, these lesions have been described to persist for several years while growing slowly, having average tissue loss of $1.3 \mathrm{~cm}^{2} \mathrm{mo}^{-1}$ (Gil-Agudelo et al. 2004). Thus, the significance of this lesion for Orbicella spp. populations has been debated (Gil-Agudelo et al. 2004). In the present study, the associated surface area of PCM was around 5 times greater than those reported in Gil-Agudelo et al. (2004), and thermal stress during the study period may have been an important contributing factor. The progression of these lesions was highly variable, and predictive gross morphologic features were not identified. Histopathological evaluation of similar lesions in Siderastrea spp. and IndoPacific corals has shown endolithic mycosis (Work \& Weil 2016). Because this lesion is significantly impacting the health of St. Kitts' Orbicella spp., histopathological examination of lesions is recommended, and comparisons among rapidly versus slowly progressing lesions may help explain pathogenesis.

Bleaching (Categories 3 and 4) was also significantly prevalent among the study population. In the present study, the bleaching occurred during a time of elevated sea surface temperature and coincided with the third global thermal bleaching event on record. During the study period, the US NOAA Coral Reef Watch program (https://coralreefwatch.noaa.gov/ satellite/index.php) classified coral bleaching heat stress levels for the Leeward Islands of the Lesser Antilles as 'bleach warning' (September), 'alert level 1' (October), and 'bleach watch' (November and December). Bleaching in tagged corals was the most severe during and immediately after the 'alert level $1^{\prime}$ timeframe, but persisted through January-April, when heat stress had subsided. The cross-sectional study (i.e. prevalence survey) was undertaken in the spring of 2017 when water temperatures were cooler, and thus prevalence of bleaching was lower at this time (AMP for diffuse bleaching: 1.0\%, 95\% CI: $0.4-$ 1.7\%; AMP focal bleaching: $2.9 \%, 95 \%$ CI: $1.8-$ $4.0 \%$ ). A mild bleaching event was also observed and attributed to unusually warm water temperatures when St. Kitts was last surveyed in 2010 (Bruckner \& Williams 2012). In the present study, the most severely affected areas of bleached corals typically followed an apical distribution, potentially indicative of solar radiation stress contributing to the bleaching observed in shallow reefs (Brown \& Dunne 2016). Orbicella spp. are known to be susceptible to thermal bleaching (Williams \& Bunkley-Williams 1988, Oxenford et al. 2008). Bleaching is often not considered to be directly responsible for losses documented in populations of Orbicella spp. over long time periods, but rather is regarded to potentiate disease progression and predispose colonies to new disease outbreaks shortly thereafter (Bruckner \& Bruckner 2006b, Bruckner 2012). In the present study, bleaching progressed to tissue loss in severely bleached areas in one coral, and appeared to worsen progression of concurrent Category 1 lesions in 3 corals, consistent with the view that bleaching and thermal stress predispose corals to other diseases (Brandt \& McManus 2009).

Lesions of focal tissue loss with skeletal erosion (Category 6) were common in St. Kitts' Orbicella spp. and are believed to most likely be the result of trauma, especially corallivory (e.g. by parrotfish, damselfish, wrasses, or angelfish). The lesions were observed to heal rapidly, as documented by others (Bruckner \& Bruckner 2006b). In contrast to another study (Bruckner \& Williams 2012), these lesions did not appear to be substantially contributing to mortality in St. Kitts' Orbicella spp.

Although much less prevalent than other lesions, annular black surface deposit with tissue loss (Category 5) was the most aggressive and rapidly progressing lesion observed in the present study. Although Orbicella spp. are known to be susceptible to this lesion (Sutherland et al. 2004), its prevalence is usually low (prevalence pooled by species: $<1 \%$; Edmunds 1991, Kuta \& Richardson 1996). The apparent predilection of this lesion for shallow corals may be explained by its etiology; a photosynthesis-dependent consortium of micro-organisms dominated by cyanobacteria (Rutzler et al. 1983). This lesion has a seasonal pattern where it is most prevalent in warmer months (Kuta \& Richardson 1996), and it follows that remission of this lesion occurred during colder months of the present study.

Multifocal grey pigmentation (Category 7) was occasionally seen in $O$. faveolata, and to the authors' knowledge has not been previously described in this 
species. However, similar grey-white pigmentation is apparently common in shallow-water massive-coral genera, particularly faviid corals, and is geographically widespread (Kramarsky-Winter et al. 2006, Siboni et al. 2010). In St. Kitts' O. faveolata, the alteration was stagnant, remaining unchanged for the entire study period; therefore, it is unclear if it is pathological. Similar pigmentation has been described in Montastraea cavernosa and affected colonies are believed to be physiologically healthy (Cruz et al. 2015). While the origin of the white-grey color is unknown, in Favia spp. it is associated with potentially symbiotic thraustochytrid protists that are aggregated in the host's mucous and superficial tissues (Siboni et al. 2010). Histopathologic and microbiologic evaluation is required to further evaluate this morphological change.

In conclusion, disease is highly prevalent in and likely contributing to declines of $O$. annularis and $O$. faveolata of shallow fringing reefs in St. Kitts. $O$. annularis and $O$. faveolata are important reef-building species that are already endangered and are unlikely to recover due to their slow growth and low reproductive activity. Annular yellow to brown pigmented lesions with chronic tissue loss and focal brown pigmentation with chronic tissue loss are the most prevalent and progressive lesions impacting the study population. Lesion morphology can inform the next stage of the investigation, which includes histopathological examination of the most prevalent and rapidly progressing lesion patterns, with targeted focus on sampling lesions showing features associated with active lesion progression.

Acknowledgements. This work was supported by an intramural grant from Ross University School of Veterinary Medicine, Center for Conservation Medicine and Ecosystem Health. Thanks to Louis-Pierre Rich who assisted with retrieval of archived sea surface temperature data, and the 'Coral Crusaders', Ross University veterinary student volunteers who helped photograph lesions of tagged corals, including Lila Batiari, Lindsay Binkow, Bec Crawford, Timothy Courtney, Michael Ferrari, Christine Ford, Taylor Huffman, Adrien Izquierdo, Jessica Kalinowski, Diane Lewis, Larissa Menke, Mandy Murti, Courtney Pearce, Kendall Putnam, Aubrey Sapala, Jenna Strapple, Laura Taylor, Alissa Tepedino, Janeice Villanueva, and Gina Zeitlin.

\section{LITERATURE CITED}

Aeby GS, Ushijima B, Campbell JE, Jones S and others (2019) Pathogenesis of a tissue loss disease affecting multiple species of corals along the Florida reef tract. Front Mar Sci 6:678

Aronson RB, Precht WF (2001) White-band disease and the changing face of Caribbean coral reefs. Hydrobiologia 460:25-38
Aronson RB, Bruckner A, Moore J, Precht B, Weil E (2008a) Acropora palmata. The IUCN Red List of Threatened Species 2008:e.T133006A3536699. http://dx.doi.org/10. 2305/IUCN.UK.2008.RLTS.T133006A3536699.en

Aronson RB, Bruckner A, Moore J, Precht B, Weil E (2008b) Montastraea annularis. The IUCN Red List of Threatened Species 2008:e.T133134A3592972. http://dx.doi. org/10.2305/IUCN.UK.2008.RLTS.T133134A3592972.en

Borger JL (2003) Three scleractinian coral diseases in Dominica, West Indies: distribution, infection patterns and contribution to coral tissue mortality. Rev Biol Trop 51(Suppl 4):25-38

Borger JL (2005) Scleractinian coral diseases in south Florida: incidence, species susceptibility, and mortality. Dis Aquat Org 67:249-258

* Brandt ME, McManus JW (2009) Disease incidence is related to bleaching extent in reef-building corals. Ecology 90:2859-2867

Brown B, Dunne R (2016) Coral bleaching: the roles of sea temperature and solar radiation. In: Woodley CM, Downs CA, Bruckener AW, Porter JW, Galloway SB (eds) Diseases of coral. John Wiley \& Sons, Hoboken, NJ, p 266-283

Bruckner A (2012) Factors contributing to the regional decline of Montastraea annularis (complex). Proc $12^{\text {th }}$ Int Coral Reef Symp, Cairns

*Bruckner AW, Bruckner RJ (2006a) Consequences of yellow band disease (YBD) on Montastraea annularis (species complex) populations on remote reefs off Mona Island, Puerto Rico. Dis Aquat Org 69:67-73

Bruckner AW, Bruckner RJ (2006b) The recent decline of Montastraea annularis (complex) coral populations in Western Curaçao: A cause for concern? Rev Biol Trop 54: 45-58

Bruckner AW, Riegl B (2016) Yellow-band diseases. In: Woodley CM, Downs CA, Bruckener AW, Porter JW, Galloway SB (eds) Diseases of coral. John Wiley \& Sons, Hoboken, NJ, p 376-386

Bruckner A, Williams A (2012) Assessment of the community structure, status, health and resilience of coral reefs off St. Kitts and Nevis. Khaled Bin Sultan Living Oceans Foundation, Landover, MD. https://www.livingoceansfoundation.org/publication/assessment-of-the-communitystructure-status-health-and-resilience-of-coral-reefs-offst-kitts-and-nevis/ (accessed 26 September 2019)

* Bruno JF, Petes LE, Harvell CD, Hettinger A (2003) Nutrient enrichment can increase the severity of coral diseases. Ecol Lett 6:1056-1061

* Budd AF, Fukami H, Smith ND, Knowlton N (2012) Taxonomic classification of the reef coral family Mussidae (Cnidaria: Anthozoa: Scleractinia). Zool J Linn Soc 166: 465-529

* Bythell JC, Hillis-Starr ZM, Rogers CS (2000) Local variability but landscape stability in coral reef communities following repeated hurricane impacts. Mar Ecol Prog Ser 204:93-100

Carpenter KE, Abrar M, Aeby G, Aronson RB and others (2008) One-third of reef-building corals face elevated extinction risk from climate change and local impacts. Science 321:560-563

* Cervino J, Goreau T, Nagelkerken I, Smith G, Hayes R (2001) Yellow band and dark spot syndromes in Caribbean corals: distribution, rate of spread, cytology, and effects on abundance and division rate of zooxanthellae. In: Porter JW (ed) The ecology and etiology of newly 
emerging marine diseases. Developments in Hydrobiology, Vol 159. Springer, Dordrecht, p 53-63

Christensen RHB (2019) ordinal: regression models for ordinal data. R package version 2019.12-10. https://CRAN.Rproject.org/package $=$ ordinal

Cróquer A, Bastidas C, Lipscomp D, Rodríguez-Martínez RE, Jordan-Dahlgren E, Guzman HM (2006) First report of folliculinid ciliates affecting Caribbean scleractinian corals. Coral Reefs 25:187-191

Cruz ICS, Leal MC, Mendes CR, Kikuchi RKP and others (2015) White but not bleached: photophysiological evidence from white Montastrea cavernosa reveals potential overestimation of coral bleaching. Mar Biol 162: 889-899

Edmunds PJ (1991) Extent and effect of black band disease on a Caribbean reef. Coral Reefs 10:161-165

Edmunds PJ (2013) Decadal-scale changes in the community structure of coral reefs of St. John, US Virgin Islands. Mar Ecol Prog Ser 489:107-123

Foley JE, Sokolow SH, Girvetz E, Foley CW, Foley P (2005) Spatial epidemiology of Caribbean yellow band syndrome in Montastrea spp. coral in the eastern Yucatan, Mexico. Hydrobiologia 548:33-40

Freeman E, Woodruff SD, Worley SJ, Lubker SJ and others (2017) ICOADS release 3.0: a major update to the historical marine climate record. Int J Climatol 37:2211-2232

Gil-Agudelo DL, Garzón-Ferreira J (2001) Spatial and seasonal variation of dark spots disease in coral communities of the Santa Marta area (Colombian Caribbean). Bull Mar Sci 69:619-629

Gil-Agudelo DL, Smith GW, Garzón-Ferreira J, Weil E, Petersen D (2004) Dark spots disease and yellow band disease, two poorly known coral diseases with high incidence in Caribbean reefs. In: Rosenberg E, Loya Y (eds) Coral health and disease. Springer, Berlin Heidelberg, p 337-349

Gladfelter WB (1982) White-band disease in Acropora palmata: implications for the structure and growth of shallow reefs. Bull Mar Sci 32:639-643

Gladfelter EH, Monahan RK, Gladfelter WB (1978) Growth rates of five reef-building corals in the Northeastern Caribbean. Bull Mar Sci 28:728-734

Higgins JPT, Green S (eds) (2011) Studies with zero-cell counts. Cochrane handbook for systematic reviews of interventions version 5.1.0. https://handbook-5-1.cochrane. org/chapter_16/16_9_2_studies_with_zero_cell_counts.htm

Jackson J, Donovan M, Cramer K, Lam V (2014) Status and trends of Caribbean coral reefs: 1970-2012. Global Coral Reef Monitoring Network, IUCN, Gland. http://cep.unep .org/publications-and-resources/technical-reports/cep_ tr_71-en.pdf/@@download/file/CEP_TR_71-en.pdf (accessed 26 September 2019)

Kohler KE, Gill SM (2006) Coral point count with excel extensions (CPCe): a visual basic program for the determination of coral and substrate coverage using random point count methodology. Comput Geosci 32:1259-1269

Kramarsky-Winter E, Harel M, Siboni N, Dov EB, Brickner I, Loya Y, Kushmaro A (2006) Identification of a protist-

Editorial responsibility: Esther Peters,

Fairfax, Virginia, USA coral association and its possible ecological role. Mar Ecol Prog Ser 317:67-73

Kramer PR, Roth LM, Constantine S, Knowles J, Cross L, Bruckner A (2016) St. Kitts and Nevis' coral reef report card 2016. The Nature Conservancy. www.nature.org/ media/coral-reef-report-cards/SKN_Report_Card_2016_ WebLowRes.pdf (accessed 26 September 2019)

Kuta KG, Richardson LL (1996) Abundance and distribution of black band disease on coral reefs in the Northern Florida Keys. Coral Reefs 15:219-223

Lee CH, Cook S, Lee JS, Han B (2016) Comparison of two meta-analysis methods: inverse-variance-weighted average and weighted sum of $Z$-scores. Genomics Inform 14 : $173-180$

Nugues M (2002) Impact of coral disease outbreak on coral communities in St. Lucia: What and how much has been lost? Mar Ecol Prog Ser 229:61-71

Oxenford HA, Roach R, Brathwaite A, Nurse L and others (2008) Quantitative observations of a major coral bleaching event in Barbados, Southeastern Caribbean. Clim Change 87:435-449

R Core Team (2017) R: a language and environment for statistical computing. R Foundation for Statistical Computing, Vienna

Raymundo LJ, Couch CS, Harvell CD (eds) (2008) Coral disease handbook: guidelines for assessment, monitoring \& management. The Coral Reef Targeted Research \& Capacity Building for Management Program, St Lucia, QLD. https://ccres.net/images/uploads/publications/7/ crtr_disease_handbook_final.pdf (accessed 26 September 2019)

Rutzler K, Santavy DL, Antonius A (1983) The black band disease of Atlantic reef corals. Mar Ecol 4:329-358

* Santavy D, Peters E, Quirolo C, Porter JW, Bianchi C (1999) Yellow-blotch disease outbreak on reefs of the San Blas Islands, Panama. Coral Reefs 18:97

Siboni N, Rasoulouniriana D, Ben-Dov E, Kramarsky-Winter E and others (2010) Stramenopile microorganisms associated with the massive coral Favia sp. J Eukaryot Microbiol 57:236-244

Sutherland KP, Porter JW, Torres C (2004) Disease and immunity in Caribbean and Indo-Pacific zooxanthellate corals. Mar Ecol Prog Ser 266:273-302

Szmant A (1991) Sexual reproduction by the Caribbean reef corals Montastraea annularis and M. cavernosa. Mar Ecol Prog Ser 74:13-25

Weil E (2004) Coral reef diseases in the wider Caribbean. In: Rosenberg E, Loya Y (eds) Coral health and disease. Springer, Berlin Heidelberg, p 35-68

Williams E Jr, Bunkley-Williams L (1988) Bleaching of Caribbean coral reef symbionts in 1987-1988. In: Proc $6^{\text {th }}$ Int Coral Reef Symp, Townsville 3:313-318

* Work TM, Aeby GS (2006) Systematically describing gross lesions in corals. Dis Aquat Org 70:155-160

* Work T, Meteyer C (2014) To understand coral disease, look at coral cells. EcoHealth 11:610-618

Work TM, Weil E (2016) Dark-spots disease. In: Diseases of coral. John Wiley \& Sons, Hoboken, NJ, 354-360

Submitted: September 26, 2019; Accepted: May 15, 2020

Proofs received from author(s): 17 July, 2020 